\title{
Ebola haemorrhagic fever
}

\author{
Heinz Feldmann, MD and \\ Laboratory of Virology, Division of Intramural Research, National Institute of Allergy and \\ Infectious Diseases, National Institutes of Health, Rocky Mountain Laboratories, Hamilton, MT, \\ USA \\ Department of Medical Microbiology, University of Manitoba, Winnipeg, MB, Canada \\ Thomas W Geisbert, PhD \\ Department of Microbiology and Immunology, University of Texas Medical Branch and Galveston \\ National Laboratory, Galveston, TX, USA
}

\section{Abstract}

Ebola viruses are the causative agents of a severe form of viral haemorrhagic fever in man, designated Ebola haemorrhagic fever, and are endemic in regions of central Africa. The exception is the species Reston Ebola virus, which has not been associated with human disease and is found in the Philippines. Ebola virus constitutes an important local public health threat in Africa, with a worldwide effect through imported infections and through the fear of misuse for biological terrorism. Ebola virus is thought to also have a detrimental effect on the great ape population in Africa. Case-fatality rates of the African species in man are as high as $90 \%$, with no prophylaxis or treatment available. Ebola virus infections are characterised by immune suppression and a systemic inflammatory response that causes impairment of the vascular, coagulation, and immune systems, leading to multiorgan failure and shock, and thus, in some ways, resembling septic shock.

\section{Introduction}

Ebola virus is regarded as the prototype pathogen of viral haemorrhagic fever, causing severe disease and high case-fatality rates. ${ }^{1}$ This high fatality, combined with the absence of treatment and vaccination options, makes Ebola virus an important public health pathogen and biothreat pathogen of category A. ${ }^{2}$

Ebola virus and Marburg virus constitute the family Filoviridae in the order of Mononegavirales. ${ }^{3}$ Filoviruses are enveloped, non-segmented, negative-stranded RNA viruses of varying morphology. These viruses have characteristic filamentous particles that give the virus family its name. ${ }^{4}$ Ebola virus particles have a uniform diameter of $80 \mathrm{~nm}$ but can greatly vary in length, with lengths up to $14000 \mathrm{~nm} .{ }^{1,3}$ The genome consists of seven genes in the order $3^{\prime}$ leader, nucleoprotein, virion protein (VP) 35, VP40, glycoprotein, VP30, VP24, RNA-dependent RNA polymerase (L) - $5^{\prime}$ trailer. ${ }^{1,3}$ With the exception of the glycoprotein gene, all genes are monocistronic, encoding for one structural protein. The

Correspondence to: Dr Heinz Feldmann, Laboratory of Virology, Division of Intramural Research, National Institute of Allergy and Infectious Diseases, National Institutes of Health, Rocky Mountain Laboratories, 903 South 4th Street, Hamilton, MT 59840, USA, feldmannh@niaid.nih.gov.

Contributors

Both authors contributed equally to concept, literature search, writing, and figure design of this Seminar.

Conflicts of interest

HF claims intellectual property for VSV-based filovirus vaccines. TWG claims intellectual property for VSV-based filovirus vaccines, adenovirus-based filovirus vaccines, and RNA interference for the treatment of filoviral infections. 
inner ribonucleoprotein complex of virion particles consists of the RNA genome encapsulated by the nucleoprotein, which associates with VP35, VP30, and RNA-dependent RNA polymerase to the functional transcriptase-replicase complex. ${ }^{5}$ The proteins of the ribonucleoprotein complex have additional functions such as the role of VP35, which is an interferon antagonist. ${ }^{6}$ VP40 serves as the matrix protein and mediates particle formation. ${ }^{7}$ VP24, another structural protein associated with the membrane, interferes with interferon signalling. ${ }^{8}$ The glycoprotein is the only transmembrane surface protein of the virus and forms trimeric spikes consisting of glycoprotein 1 and glycoprotein 2-two disulphidelinked furin-cleavage fragments. ${ }^{1}$ An important distinction of Ebola virus from other Mononegavirales is the production of a soluble glycoprotein, which is the primary product of the GP gene, and gets secreted to large quantities from infected cells. ${ }^{9,10}$

Despite important achievements during the past two decades to unravel the molecular biology and pathogenesis of Ebola virus, we are still unclear about virulence factors and host responses, which seem to be partly detrimental to the host. The scarce knowledge has long hampered the development of proper treatment methods and vaccines, although some vaccines have now shown promise in experimental studies. ${ }^{11}$ This Seminar reviews the present knowledge about the epidemiology, ecology, disease manifestation, pathogenesis, and case management of Ebola haemorrhagic fever.

\section{Epidemiology}

The first cases of filovirus haemorrhagic fever were reported in 1967 in Germany and the former Yugoslavia, and the causative agent was identified as Marburg virus. ${ }^{12}$ Similar cases of haemorrhagic fever were described in 1976 from outbreaks in two neighbouring locations: first in southern Sudan and subsequently in northern Zaire, now Democratic Republic of the Congo (DRC). ${ }^{13,14}$ An unknown causative agent was isolated from patients in both outbreaks and named Ebola virus after a small river in northwestern DRC. These two epidemics were caused by two distinct species of Ebola virus, Sudan Ebola virus and Zaire Ebola virus, a fact not recognised until years later (figure 1). ${ }^{15}$ The third African Ebola virus species, Côte d'Ivoire Ebola virus was discovered in 1994. The virus was isolated from an infected ethnologist who had worked in the Tai Forest reserve in Côte d'Ivoire and had done a necropsy on a chimpanzee. The animal came from a troop that had lost several members to an illness later identified as Ebola haemorrhagic fever (figure 1). ${ }^{16}$ The latest discovery is Bundibugyo Ebola virus, the fourth African species of human-pathogenic Ebola virus found in equatorial Africa (approximate distribution $10^{\circ}$ north and south of the equator, figure 1). ${ }^{17}$ An additional Ebola virus species, Reston Ebola virus, is found in the Philippines. It was first described in 1989 and isolated from Cynomolgus monkeys (Macaca fascicularis) housed at a quarantine facility in Reston, VA, USA. These monkeys were imported from the Philippines; an unusually high mortality was noted in infected animals during quarantine, but simian haemorrhagic fever virus co-circulated in the animals (figure 1). ${ }^{18,19}$ Subsequently, Reston Ebola virus has been found in the Philippines on several occasions, ${ }^{20}$ with surprising reports documenting infections in pigs (figure 1). ${ }^{21}$

Ebola haemorrhagic fever remains a plague for the population of equatorial Africa, with an increase in the numbers of outbreaks and cases since 2000 (figure 1). Almost all human cases are due to the emergence or reemergence of Zaire Ebola virus in regions of Gabon, Republic of the Congo, and DRC, and of Sudan Ebola virus in Sudan and Uganda. ${ }^{1}$ These two species together with the single species of Marburg virus, Lake Victoria Marburg virus, are major public health concerns in these regions. The role of Bundibugyo Evola virus and Côte d'Ivoire Ebola virus in the occurrence of filovirial haemorrhagic fever in equatorial Africa is not clear since only one outbreak of Bundibugyo Ebola virus has occurred, ${ }^{17}$ and the Côte d'Ivoire virus has not yet reemerged since the original episode in 1994. The 
presence of Ebola virus in equatorial Africa has been supported by various serosurveys of selected populations in the region, done during the past three to four decades, indicating that the virus, or unknown pathogens that are serologically cross-reactive, are endemic in the region. ${ }^{1,22,23}$ Additionally, the emergence of Reston Ebola virus in pigs $^{21}$ raises important concerns for public health, agriculture, and food safety in the Philippines and could turn into a serious issue for parts of Asia.

\section{Ecology}

Ebola haemorrhagic fever is thought to be a classic zoonosis with persistence of the Ebola virus in a reservoir species generally found in endemic areas. Apes, man, and perhaps other mammalian species that are susceptible to Ebola virus infection are regarded as end hosts and not as reservoir species. ${ }^{22}$ Although much effort has been made to identify the natural reservoirs with every large outbreak of Ebola haemorrhagic fever, neither potential hosts nor arthropod vectors have been identified. ${ }^{23-26}$ Rodents $^{27}$ and bats ${ }^{28}$ have long been thought to be potential reservoir species. This idea was supported by experimental studies in African plants and animals that resulted in productive infection of African fruit and insectivorous bats with Zaire Ebola virus, but a firm link could not be established. ${ }^{29}$ The first evidence for the presence of Zaire Ebola virus in naturally infected fruit bats was documented by detection of viral RNA and antibodies in three tree-roosting species: Hypsignathus monstrosus, Epomops franqueti, and Myonycteris torquata. ${ }^{30,31}$ However, despite efforts, Zaire Ebola virus has not been successfully isolated from naturally infected animals. The identification and successful isolation of Marburg virus from the cave-dwelling fruit bat Rousettus aegyptiacus further lends support to the idea of bats as a reservoir species for filoviruses..$^{32}$ This finding is reassuring since several of the Marburg virus outbreaks have been associated with caves or mines that are usually heavily infested by bats. ${ }^{33}$ Data for potential reservoirs for any of the other four Ebola virus species do not exist.

Infections with Ebola virus are rare in equatorial Africa, although probably under-reported. Transmission from the reservoir species to man or other end hosts might therefore be an infrequent event, given the restricted distribution of or restricted contact with the reservoir species. However, bats are frequently encountered in equatorial Africa and hunted for food in many places. ${ }^{34}$ Therefore, Ebola virus might persist as an asymptomatic or subclinical infection in the reservoir species, with little or no transmission, and might be sporadically activated through an appropriate stimulus. The stimulus might be stress, co-infection, change in food sources, and pregnancy, as shown experimentally in vivo and in vitro. ${ }^{35,36}$ This hypothesis would explain the sporadic nature and periodicity of outbreaks of Ebola haemorrhagic fever in Africa.

Future studies need to address the extent of infections of Ebola viruses in fruit or insectivorous bats in areas endemic for these viruses. Issues such as virus pathology and persistence in bats, potential activation mechanisms of persistent virus, and potential transmission routes need to be addressed by field and experimental studies. However, one should keep an open mind for the existence of other reservoir species and a role for potential amplifying hosts, especially after the discovery of Reston Ebola virus in pigs in the Philippines. $^{21}$

\section{Clinical manifestations}

The different species of Ebola virus seem to cause somewhat different clinical syndromes, but opportunities for close observation of the diseases under good conditions have been rare. Generally, the abrupt onset of Ebola haemorrhagic fever follows an incubation period of 221 days (mean 4-10) and is characterised by fever, chills, malaise, and myalgia. The subsequent signs and symptoms indicate multisystem involvement and include systemic 
(prostration), gastrointestinal (anorexia, nausea, vomiting, abdominal pain, diarrhoea), respiratory (chest pain, shortness of breath, cough, nasal discharge), vascular (conjunctival injection, postural hypotension, oedema), and neurological (headache, confusion, coma) manifestations. Haemorrhagic manifestations arise during the peak of the illness and include petechiae, ecchymoses, uncontrolled oozing from venepuncture sites, mucosal haemorrhages, and post-mortem evidence of visceral haemorrhagic effusions. A macropapular rash associated with varying severity of erythema and desquamate can often be noted by day $5-7$ of the illness; this symptom is a valuable differential diagnostic feature and is usually followed by desquamation in survivors. Abdominal pain is sometimes associated with hyperamylasaemia and true pancreatitis. In later stages, shock, convulsions, severe metabolic disturbances, and, in more than half the cases, diffuse coagulopathy supervene. . $^{1,37-39}$

Laboratory variables are less characteristic but the following findings are often associated with Ebola haemorrhagic fever: early leucopenia (as low as 1000 cells per $\mu \mathrm{L}$ ) with lymphopenia and subsequent neutrophilia, left shift with atypical lymphocytes, thrombocytopenia (50000-100000 cells per $\mu \mathrm{L}$ ), highly raised serum aminotransferase concentrations (aspartate aminotransferase typically exceeding alanine aminotransferase), hyperproteinaemia, and proteinuria. Prothrombin and partial thromboplastin times are extended and fibrin split products are detectable, indicating diffuse intravascular coagulopathy. In a later stage, secondary bacterial infection might lead to raised counts of white blood cells. ${ }^{1,37-39}$

Patients with fatal disease develop clinical signs early during infection and die typically between day 6 and 16 with hypovolaemic shock and multiorgan failure. Haemorrhages can be severe but are only present in fewer than half of patients. In non-fatal cases, patients have fever for several days and improve typically around day 6-11, about the time that the humoral antibody response is noted..$^{1,40}$ Patients with non-fatal or asymptomatic disease mount specific IgM and IgG responses that seem to be associated with a temporary early and strong inflammatory response, including interleukin $\beta$, interleukin 6 , and tumour necrosis factor a $(\mathrm{TNFa})$. However, whether this is the mechanism for protection from fatal disease remains to be proven. ${ }^{1}$ Convalescence is extended and often associated with sequelae such as myelitis, recurrent hepatitis, psychosis, or uveitis. ${ }^{1,41}$ Pregnant women have an increased risk of miscarriage, and clinical findings suggest a high death rate for children of infected mothers. This high death rate could be due to transmission from the infected mother to the child during breastfeeding, either through milk or close contact.

The virulence of Ebola virus in man is variable and is dependent on the species or strain; a similar variability seems to recapitulate well in non-human primates. Within the genus Ebola virus, infections with the Zaire Ebola virus species have the highest case-fatality rates (6090\%) followed by those for the Sudan Ebola virus species (40-60\%). On the basis of one outbreak, case-fatality rates for Bundibugyo strain infections are estimated to be only $25 \%$. The only reported person infected with Côte d'Ivoire Ebola virus became ill but survived. ${ }^{16}$ By comparison, case-fatality rates for Marburg virus infection in Africa are 70-85\% but were much lower in the outbreak in Europe in 1967, with a case-fatality rate of only $22 \%$. This low rate has led to speculation that proper intensive care with supportive therapy would increase the survival rate of infected patients. This hypothesis is hard to test because of austere field conditions and ethical dilemmas about not providing care to some patients. Reston Ebola virus is deemed nonpathogenic for man, but laboratory tests have documented the occurrence of infection. ${ }^{1}$ 


\section{Pathogenesis}

Information about the pathology and pathogenesis of Ebola virus infections in man is sparse. This shortcoming is partly attributable to the inaccessibility of the geographical regions in which these natural infections arise. However, comprehensive studies have been done in animals. Rodents such as guineapigs and mice have been used to study Ebola haemorrhagic fever. ${ }^{42-44}$ Because isolates of Ebola virus obtained from primates do not typically produce severe disease in rodents on initial exposure, serial adaptation is needed to produce a uniformly lethal infection. Mice and guineapigs have served well as early screens for assessment of antiviral drugs and candidate vaccines, and genetically engineered mice are clearly useful for the dissection of specific host-pathogen interactions. However, the disease pathogenesis recorded in rodents is less accurate in representation of the human disorder than is the disease recorded in non-human primates. ${ }^{45,46}$

\section{Route of infection}

Ebola virus seems to enter the host through mucosal surfaces, breaks, and abrasions in the skin, or by parenteral introduction. Most human infections in outbreaks seem to occur by direct contact with infected patients or cadavers. ${ }^{13,14,47,48}$ Infectious virus particles or viral RNA have been detected in semen, genital secretions, ${ }^{40,49}$ and in skin of infected patients, 50 they have also been isolated from skin, body fluids, and nasal secretions of experimentally infected non-human primates. ${ }^{51,52}$

Laboratory exposure through needlestick and blood has been reported ${ }^{53-55}$ Reuse of contaminated needles played an important part in the 1976 outbreaks of Ebola virus in Sudan and Zaire. ${ }^{13,14}$ Butchering of a chimpanzee for food was linked to outbreaks of Zaire Ebola virus in Gabon, ${ }^{56}$ and contact exposure was the probable route of transmission. Although proper cooking of foods should inactivate infectious Ebola virus, ingestion of contaminated food cannot wholly be ruled out as a possible route of exposure in natural infections. Notably, handling and consumption of freshly killed bats was associated with an outbreak of Zaire Ebola virus in DRC. ${ }^{34}$ Organ infectivity titres in non-human primates infected with Ebola virus are frequently in the range of $10^{7}$ to $10^{8} \mathrm{pfu} / \mathrm{g} ;{ }^{51}$ thus, exposure through the oral route could invariably be associated with very high infectious doses. In fact, Zaire Ebola virus is highly lethal when given orally to rhesus macaques. ${ }^{57}$ The role of aerosol transmission in outbreaks is unknown, but is thought to be rare.

In human beings, the route of infection seems to affect the disease course and outcome. The mean incubation period for cases of Zaire Ebola virus infection known to be due to injection is $6 \cdot 3$ days, versus $9 \cdot 5$ days for contact exposures. ${ }^{58}$ Moreover, the case-fatality rate in the 1976 outbreak of Zaire Ebola virus was $100 \%$ ( 85 of 85 ) in cases associated with injection compared with about $80 \%$ (119 of 149) in cases of known contact exposure. ${ }^{58}$ For nonhuman primates infected with Zaire Ebola virus, the disease course seems to progress faster in animals exposed by intramuscular or intraperitoneal injection than in animals exposed by aerosol droplets. ${ }^{59}$

\section{Target cells and tissues}

Ebola virus has a broad cell tropism, infecting a wide range of cell types. In-situ hybridisation and electron microscopic analyses of tissues from patients with fatal disease or from experimentally infected non-human primates show that monocytes, macrophages, dendritic cells, endothelial cells, fibroblasts, hepatocytes, adrenal cortical cells, and several types of epithelial cells all lend support to replication of these viruses. ${ }^{50,51,57,60-63}$ Temporal studies in non-human primates experimentally infected with Zaire Ebola virus suggest that monocytes, macrophages, and dendritic cells are early and preferred replication sites of 
these viruses (figure 2). ${ }^{62}$ These cells seem to have pivotal roles in dissemination of the virus as it spreads from the initial infection site via monocytes, macrophages, and dendritic cells to regional lymph nodes, probably through the lymphatic system, and to the liver and spleen through the blood. ${ }^{62,64}$ Monocytes, macrophages, and dendritic cells infected with Ebola virus migrate out of the spleen and lymph nodes to other tissues, thus disseminating the infection (figure 2).

Although the endothelium is thought to play an important part in the pathogenesis of Ebola virus (figure 2), studies defining the molecular mechanisms of endothelial impairment are incomplete. Researchers thought that the virus' glycoprotein is the primary determinant of vascular-cell injury and that Ebola virus infection of endothelial cells induces structural damage ${ }^{65}$ which could contribute to the haemorrhagic diathesis. However, histological analysis of autopsy tissues from several of the early outbreaks did not identify vascular lesions, ${ }^{66}$ and no vascular lesions in any subsequent studies have been reported so far. Similarly, no evidence of substantial vascular lesions in non-human primates infected with Ebola virus exists. ${ }^{57,60-62}$ In one temporal study in cynomolgus macaques, infection of endothelial cells by Zaire Ebola virus was infrequent and was mainly restricted to the terminal stages of disease. ${ }^{62}$

Together with the macrophage-rich lymphoid tissues, the liver and the adrenal gland seem to be important targets for filoviruses (figure 2), and this tropism probably has an equally important role in the disease pathogenesis. Various degrees of hepatocellular necrosis have been reported in infected people and non-human primates; ${ }^{1,13,51,57,66}$ however, the hepatocellular lesions are generally not serious enough to explain the cause of death. Importantly, haemorrhagic tendencies could be related to decreased synthesis of coagulation and other plasma proteins because of severe hepatocellular necrosis. Adrenocortical infection and necrosis have also been reported in humans and non-human primates infected with Ebola virus. ${ }^{1,51}$ The adrenal cortex plays an important part in control of blood pressure homoeostasis. Impaired secretion of enzymes that synthesise steroids leads to hypotension and sodium loss with hypovolaemia, which are important elements that have been reported in nearly all cases of Ebola haemorrhagic fever. ${ }^{1}$ Impairment of adrenocortical function by Ebola virus infection could therefore have an especially important role in the evolution of shock that typifies late stages of Ebola haemorrhagic fever (figure 2).

During infection with Ebola virus, lymphoid depletion and necrosis are often noted in spleen, thymus, and lymph nodes of patients with fatal disease and in non-human primates that are experimentally infected (figure 2). ${ }^{1,13,51,61,63}$ Although lymphoid tissues are primary sites of Ebola virus infection, there is usually little inflammatory cellular response in these or other infected tissues. Despite the large die-off and loss of lymphocytes during infection, the lymphocytes themselves are not infected. Large numbers of lymphocytes undergo apoptosis in man as well a in non-human primates experimentally infected with Ebola virus, ${ }^{51,67-69}$ partly explaining the progressive lymphopenia and lymphoid depletion at death (figure 2). In the 2000 outbreak of Sudan Ebola virus in Uganda, a decrease in the number of circulating $\mathrm{T}$ lymphocytes was noted in people with fatal disease whereas cell count did not fall significantly in patients who survived the disease. ${ }^{70}$ In macaques infected with Zaire Ebola virus, the lymphocyte loss seemed to be greatest in the T-lymphocyte and natural-killer cell populations. ${ }^{51}$

The mechanism for the underlying apoptosis and loss of bystander lymphocytes during the course of Ebola haemorrhagic fever are unknown but are thought to be provoked through several different agonists or pathways. These pathways or processes might include the TNFrelated apoptosis-inducing ligand (TRAIL) and Fas death receptor pathways, ${ }^{51,71}$ impairment of dendritic cell function induced by Ebola virus infection, ${ }^{51,72,73}$ abnormal 
production of soluble mediators such as nitric oxide that have proapoptotic properties, $1,51,71,74$ or possibly by direct interactions between lymphocytes and Ebola virus proteins (figure 2). The recognition of an immunosuppressive motif in the carboxyl-terminal region of the virus' glycoproteins lends support to the notion that virus particles or proteins might partly contribute to the dysfunction or the loss of lymphocytes, or both. ${ }^{75-77}$

\section{Host immune response}

Ebola virus infection triggers the expression of several inflammatory mediators including interferons; interleukins 2, 6, 8, and 10; interferon-inducible protein 10; monocyte chemoattractant protein 1; regulated upon activation normal $\mathrm{T}$ cell expressed and secreted (RANTES); TNFa; and reactive oxygen and nitrogen species (figure 2). 1,51,67,71,74,78 Results from studies of various primary human cells in vitro also show that infection of Ebola virus can trigger the production of many of these same inflammatory mediators. ${ }^{62,71,79}$ Although monocytes or macrophages seem to produce many of these mediators, as shown in vitro, other cell types could produce inflammatory mediators in the intact animal. Overall, virus-induced expression of these mediators seems to result in an immunological imbalance that partly contributes to the progression of disease.

Proinflammatory responses recorded in fatal cases of Ebola haemorrhagic fever are disregulated, whereas early and well regulated inflammatory responses have been associated with recovery. ${ }^{80}$

Inhibition of the type I interferon response, initially noted by studies of endothelial cells infected with Zaire Ebola virus, ${ }^{81,82}$ seems to be a key feature of filovirus pathogenesis. The Ebola virus VP35 functioned as a type I interferon antagonist ${ }^{6,83,84}$ by blocking activation of interferon regulatory factor 3 and possibly by preventing transcription of interferon $\beta .^{83}$ Additionally, other studies suggest that expression of VP24 of the Ebola virus interferes with type I interferon signalling; 8,84 mutations in VP24 have been linked to adaptation of Zaire Ebola virus to produce lethal disease in mice ${ }^{85}$ and guineapigs. ${ }^{86}$

Results from several studies show an important role for reactive oxygen and nitrogen species in pathogenesis of Ebola haemorrhagic fever (figure 2). Increased concentrations of nitric oxide in blood were reported in non-human primates experimentally infected with Zaire Ebola virus ${ }^{51,71}$ and were noted in patients infected with Zaire Ebola virus and Sudan Ebola virus. $^{70,74}$ Increased blood concentrations of nitric oxide in patients were associated with mortality. ${ }^{70}$ Abnormal production of nitric oxide has been associated with several pathological disorders including apoptosis of bystander lymphocytes, tissue damage, and loss of vascular integrity, which might contribute to virus-induced shock. Nitric oxide is an important mediator of hypotension, and hypotension is a prominent finding in most of the viral haemorrhagic fevers including those caused by Ebola virus (figure 2).

\section{Impairment of coagulation}

Defects in blood coagulation and fibrinolysis during Ebola virus infections are manifested as petechiae, ecchymoses, mucosal haemorrhages, congestion, and uncontrolled bleeding at venepuncture sites (figures 2 and 3). However, massive loss of blood is infrequent and, when present, is mainly limited to the gastrointestinal tract (figure 3). Even in these cases, the amount of blood that is lost is not substantial enough to cause death. Thrombocytopenia, consumption of clotting factors, and increased concentrations of fibrin degradation products are other indicators of the coagulopathy that characterises Ebola virus infections. Results from clinical laboratory data strongly suggest that the coagulation abnormalities that occur during human Ebola haemorrhagic fever ${ }^{14,87}$ are generally consistent with disseminated intravascular coagulation. ${ }^{88}$ Furthermore, results from many studies have shown histological 
and biochemical evidence of disseminated intravascular coagulation during Ebola virus infection in several non-human primate species (figure 3). $45,46,51,57,61,89-91$

The mechanism responsible for triggering the coagulation disorders that typify Ebola haemorrhagic fever are not wholly understood. Results from several studies strongly suggest that expression or release of tissue factor from monocytes and macrophages infected with Ebola virus are key factors that induce the development of coagulation irregularities reported in Ebola haemorrhagic fever ${ }^{91}$ However, coagulopathy noted during Ebola haemorrhagic fever could be caused by several factors, especially during the later stages of disease. For example, rapid reductions in plasma concentrations of the natural anticoagulant protein $\mathrm{C}$ were recorded during the course of Zaire Ebola virus infection of cynomolgus monkeys. ${ }^{91}$

Together, the data so far suggest that an impaired and ineffective host response leads to high concentrations of virus and proinflammatory mediators in the late stages of disease, which is important in the pathogenesis of haemorrhage and shock. The prevailing hypothesis at this time is that infection and activation of antigen-presenting cells is fundamental to the development of Ebola haemorrhagic fever. The release of proinflammatory cytokines, chemokines, and other mediators from antigen presenting cells, and perhaps other cells, causes impairment of the vascular and coagulation systems leading to multiorgan failure and a syndrome that in some ways resembles septic shock (figure 2).

\section{Diagnosis}

Ebola haemorrhagic fever presents as a viral prodrome with a high potential for differential diagnosis, especially early in outbreaks. The initial diagnosis of this syndrome is based on clinical assessment. Therefore, proper contingency plans should be developed. Several imported cases of the closely related Marburg virus have been reported in Europe and the USA. ${ }^{92,93}$ Ebola haemorrhagic fever can be suspected in acute febrile patients with the symptoms described and with a history of travel to an endemic area, if they present with fever and constitutional symptoms. Identification might be difficult because severe and acute febrile diseases can have a wide range of causes in areas endemic for Ebola virus, with the most prominent being malaria and typhoid fever followed by others such as shigellosis, menigococcal septicaemia, plague, leptospirosis, anthrax, relapsing fever, typhus, murine typhus, yellow fever, Chikungunya fever, and fulminant viral hepatitis. ${ }^{1}$

Laboratory diagnosis for viral haemorrhagic fevers is generally done in national and international reference centres, which should be contacted immediately on suspicion for advice on sampling, sample preparation, and sample transport. Laboratory diagnosis of Ebola virus is achieved in two ways: measurement of host-specific immune responses to infection and detection of viral particles, or particle components in infected individuals. Nowadays, RT-PCR ${ }^{1,94}$ and antigen detection ELISA ${ }^{1,94}$ are the primary assays to diagnose an acute infection. Viral antigen and nucleic acid can be detected in blood from day 3 up to 7-16 days after onset of symptoms. ${ }^{41}$ For antibody detection the most generally used assays are direct IgG and IgM ELISAs and IgM capture ELISA. ${ }^{1,94}$ IgM antibodies can appear as early as 2 days post onset of symptoms and disappear between 30 and 168 days after infection. IgG-specific antibodies develop between day 6 and 18 after onset and persist for many years. ${ }^{41} \mathrm{~A}$ IgM or rising IgG titre constitutes a strong presumptive diagnosis. Decreasing IgM, or increasing IgG titres (four-fold), or both, in successive paired serum samples are highly suggestive of a recent infection. ${ }^{1,94}$ All these assays can be done on materials that have been rendered non-infectious. An efficient way to inactivate the virus for antigen and antibody detection is the use of gamma irradiation from a cobalt-60 source or heat inactivation. ${ }^{95}$ Similarly, the nucleic acid can be amplified by purification of the virus 
RNA from materials treated with guanidinium isothiocyanate-a chemical chaotrope that denatures the proteins of the virus and renders the sample non-infectious. ${ }^{96}$

Repeated Ebola virus outbreaks in several countries of equatorial Africa have occurred in recent years. ${ }^{97}$ Often these outbreaks occur in remote sites where advanced medical support systems are scarce and timely diagnostic services are very difficult to provide. Provision of basic on-site diagnostics, including confounding differential diagnosis, could help with the management of patients specifically and with the outbreak in general. The development of truly portable real-time thermocyclers and simple serological assays appropriate for field use has made the provision of a field diagnostic laboratory a reasonable undertaking. ${ }^{1,94,98,99}$ However, the launch of diagnostic support in remote areas of equatorial Africa can be logistically and technically difficult since these regions are austere environments with cultural differences and sometimes hostile behaviour.

\section{Management}

Case management is based on isolation of patients and use of strict barrier nursing procedures, such as protective clothing and respirators. These procedures have been sufficient to rapidly interrupt transmission in hospital settings in rural Africa. For members of rural African communities, cadavers are residual risks and should be handled accordingly. Traditional funeral and caretaking methods contribute to the spread of the virus and potentiate outbreaks. Methods to achieve barrier nursing, waste disposal, and other key elements inexpensively and practically in Africa have been devised, and field-tested manuals are available. ${ }^{47,100,101}$ Important elements for outbreak prevention are provision of sterile equipment for injections, which is remarkably and tragically missing in Africa, and personal protective equipment to doctors, nurses, and caretakers, who are at high risk of contraction of infections in hospitals.

As a part of their contingency plans, many developed countries have established proper isolation and intensive care units to deal with imported cases. ${ }^{102,103}$ Whether patients with viral haemorrhagic fever should be transported at later stages of disease is a persistent debate. Nevertheless, any hospital should be safely capable of minimum management of Ebola and other viral haemorrhagic fevers, and should prioritise an initial crucial assessment and an early rapid diagnosis.

Present treatment strategies are mainly symptomatic and supportive. In developing countries with minimum health-care provision, these strategies should include isolation, malaria treatment, broad spectrum antibiotics, and antipyretics before diagnosis. Fluid substitution, preferentially intravenous administration, and analgesics should be provided as needed. In developed health-care systems with appropriate isolation units, proper intensive care treatment might be advised and should be directed towards maintenance of effective blood volume and electrolyte balance. Shock, cerebral oedema, renal failure, coagulation disorders, and secondary bacterial infection have to be managed and can be life-saving. Organ failure should be addressed appropriately—eg, dialysis for kidney failure and extracorporeal membrane oxygenation for lung failure. At present, no strategy has proved successful in specific pre-exposure and postexposure treatment of Ebola virus infections in man (table).

\section{Investigational treatments}

Ribavirin, a drug that is believed to interfere with capping of viral mRNAs and has been used to treat viral haemorrhagic fevers caused by arenaviruses and bunyaviruses, has no invitro or in-vivo effect on filoviruses. ${ }^{104,105}$ Therefore, and because of potential severe 
adverse effects associated with the drug, ribavirin is not recommended for Ebola virus infections.

With regard to RNA-based treatments, strategies to interfere with transcription and replication include the use of antisense oligonucleotides or RNA interference. ${ }^{106,107}$ The approaches are promising on the basis of efficacy in rodents and non-human primates infected with Zaire Ebola virus (table). ${ }^{108}$ RNA interference and antisense oligonucleotidebased approaches might be limited by the sequences for a particular Ebola virus species, which might not be known at the early stages of an outbreak. Additionally, these therapies are currently delivered intravenously, which might present logistical challenges in remote outbreak settings.

Treatment of the coagulation abnormalities recorded in Ebola virus infections should be considered (table). The nematode-derived anticoagulation protein rNAPc2 has shown 33\% efficacy in the treatment of non-human primates infected with Zaire Ebola virus. ${ }^{109} \mathrm{D}$-dimer formation has been identified as an early event during Ebola virus infection in non-human primates and could be used as a marker for treatment. ${ }^{91}$ Because rNAPc 2 targets signalling mainly through the extrinsic blood coagulation pathway, additional benefits might be gained with inhibitors of factor $\mathrm{X}$, thus targeting the most common pathway of the extrinsic and intrinsic blood coagulation pathways (table). Additional substitution of protein $\mathrm{C}$ might be beneficial by activation of one of the crucial anticoagulant mechanisms in blood. ${ }^{91}$ Results from a study showed that treatment of rhesus monkeys infected with Zaire Ebola virus with recombinant human activated protein $C$ resulted in some protection of the animals, which is consistent with survival recorded with rNAPc2 (table). ${ }^{110}$ All these drugs have been approved for different applications in man and could be easily and safely used in emergencies.

Recombinant vaccines against Ebola virus based on vesicular stomatitis virus ${ }^{111}$ have shown remarkable usefulness when given as a postexposure treatment against Ebola haemorrhagic fever in non-human primates infected with Zaire Ebola virus and Sudan Ebola virus. ${ }^{112,113}$ In a laboratory event, a recombinant vesicular stomatitis virus expressing the Zaire Ebola virus glycoprotein was given to a woman shortly after exposure with Zaire Ebola virus. ${ }^{114}$ The patient developed fever, headache, and myalgia hours after injection, which was successfully controlled with analgesics and antipyretics. Other adverse effects were not reported, but whether the treatment was effective or the patient never got infected with the virus remains uncertain. As with RNA-based treatments, postexposure vaccination with vaccines based on vesicular stomatitis virus will need some knowledge of the species involved since little cross-protection seems to exist between the various Ebola virus species.

Human convalescent blood or serum has been used for passive immunisation to treat patients naturally infected or non-human primates experimentally infected with Ebola virus, ${ }^{115,116}$ but the success is controversial. In vitro, neutralising monoclonal antibodies specific for the glycoprotein of Ebola virus generated from different species, including man, showed protective and therapeutic properties in rodents. ${ }^{117-119}$ However, antibody treatment with equine immunoglobulin against Ebola virus, ${ }^{120,121}$ with polyclonal whole blood from rhesus monkeys immune against Ebola virus, ${ }^{122}$ or with a recombinant human monoclonal antibody ${ }^{123}$ did not protect non-human primates from lethal infection with Ebola virus. Although no definite therapeutic conclusion can be drawn from the studies done so far, data suggest the value, in principle, of passively acquired antibodies in reduction of the viral burden during infection. Thus, antibody therapy, perhaps in combination with other pharmaceutical agents, might be beneficial (table). 
In view of the severe and rapid progression of Ebola haemorrhagic fever, no one therapy is likely to be sufficiently potent, which strongly favours combination therapy as the best choice. A suitable strategy might be to slow down virus replication and disease progression and to allow innate and adaptive immune responses to overcome infection. ${ }^{115,124}$ This idea is supported by data showing that viraemia lower than $1 \times 10^{4 \cdot 5} \mathrm{pfu} / \mathrm{mL}$ of blood is strongly associated with survival of patients and non-human primates infected experimentally. $1,51,110,112$

\section{Prevention}

Previously, the usefulness of an Ebola virus vaccine was disputed, because of the disease's rarity, little interest by industry, and the potential cost. Frequent outbreaks in the past decade, several imported cases of viral haemorrhagic fever and laboratory exposures, and the potential misuse of Ebola virus as a biothreat agent has changed that view. Vaccine development is part of many nations' efforts in response to the public health threat posed by emerging or re-emerging biothreat pathogens such as Ebola virus. A protective vaccine would be very valuable not only for at-risk medical personnel, first responders, military personnel, and researchers, but also for targeted vaccination in affected populations, especially during outbreaks, for use in a so-called ring vaccination strategy.

At present, vaccine candidates to be considered should show efficacy in at least two animal models of the disease including non-human primates, the gold standard animal model for viral haemorrhagic fever caused by several pathogens such as Ebola virus. ${ }^{46}$ Only a few vaccine platforms have passed these requirements and are considered for further investigation and perhaps for clinical trials. These vaccine candidates are based on recombinant technologies that use either generated replication-deficient or attenuated replication-competent platforms.

Among the replication-deficient platforms, human-adenovirus-type-5 vectors have been the first successful strategies to protect non-human primates from lethal Ebola virus challenge (table). Originally a DNA prime (glycoprotein and nucleoprotein) adenovirus boost (glycoprotein) approach was used, ${ }^{125}$ which was subsequently replaced with an accelerated approach of one immunisation with a recombinant adenovirus expressing the Zaire Ebola virus glycoprotein 28 days before challenge. ${ }^{126}$ The approach has been further developed by others by use of a multivalent adenovirus technology for the development of a panfilovirus vaccine that provides protection against several filovirus species. ${ }^{127}$ The adenovirus platform seems safe and robust but is weakened by pre-existing immunity 128 in the world population and its failure in an HIV/AIDS trial. ${ }^{129}$ The second successful approach with replication-deficient platforms is based on Ebola virus-like particles generated by coexpression of the viral matrix protein (VP40), nucleoprotein, and glycoprotein (table). ${ }^{130}$ This approach seems to best address safety issues but might need adjuvant and still needs booster immunisation for efficacy in non-human primates, which is not favourable for emergency use. Other issues are associated with the costs and production of the virus-like particle (VLP) vaccines compared with viral vector-based platforms. Reverse genetics has generated the first new generation inactivated Ebola virus vaccine by deletion of an essential gene rendering the resulting virus replication deficient. ${ }^{131,132}$ This technology allows largescale production, but remaining safety issues still need to be addressed for potential future use of this technology in generation of promising vaccine candidates.

Generally, live attenuated viruses are more advantageous than are non-replicating vaccines because of ease of production and their potent stimulation of innate and adaptive (humoural and cellular) immune responses. However, this idea does not seem feasible for Ebola virus because of difficulties in ensuring the safety of live attenuated Ebola virus strains. However, 
live attenuated recombinant Ebola virus vaccine vectors have been developed on the basis of the background of less virulent viral systems such as vesicular stomatitis virus ${ }^{111}$ and human parainfluenza virus (table). ${ }^{133,134}$ The system based on vesicular stomatitis virus has shown tremendous efficacy in non-human primates including both prophylactic and postexposure treatment situations. ${ }^{112,113,135}$ These potent vaccine platforms are associated with safety issues despite having a clean record in laboratory animals including immune-deficient animals. ${ }^{136}$ As with adenovirus vectors, pre-existing immunity might be an issue with the human parainfluenza virus ${ }^{137}$ platform but is negligible for vesicular stomatitis virus. Vaccine platforms of human parainfluenza and vesicular stomatitis viruses might have potential for delivery without use of needles. ${ }^{134,138}$

Despite good to excellent protective efficacy in animals, correlates and mechanisms of protection have not been well defined for most of the vaccine candidates mentioned in this Seminar. On the basis of present data, antibody responses, T-cell proliferation, and cytotoxic-T-lymphocyte responses show that antibody and T-helper cell memory are essential for protection, and that cell-mediated immunity, although possibly important, is not an absolute requirement. Total antibody response is thought to be a correlate for protection for Ebola virus vaccines. ${ }^{139}$ Finally, a multivalent preventive vaccine is clearly needed to provide protection against all species of Ebola viruses and Marburg viruses, and such a vaccine will possibly need at least three components. ${ }^{140}$

\section{Conclusions}

Substantial progress has been made during past decades in the understanding of the biology and pathogenesis of Ebola virus infections in vitro and in vivo. The identification of bats as potential reservoir species is a milestone, with implications for public health. Substantial progress has also been achieved in the development of countermeasures, with rapid diagnostics being implemented in developed settings and with some promising therapeutics and vaccine candidates having entered or being close to entering clinical trials. However, most of our knowledge is based on infections with Zaire Ebola virus, the most pathogenic species within the genus Ebolavirus, and on studies done in non-human primates. The other species of Ebola virus are genetically and serologically distinct, might differ in their ecology, and possess biological characteristics that make them less virulent in man.

Future efforts need to focus on the knowledge gaps about other species of Ebola virus. To prevent primary transmission from bats to man, we need more field studies into the ecology of reservoir species and their infection status and shedding mechanisms. More detailed investigations into the pathophysiology of Ebola virus infections with laboratory animals should provide us with new targets for intervention strategies. Promising therapeutics and vaccines need to be moved forward into clinical trials, and provision needs to be made for emergencies such as laboratory exposures. Finally, we urgently need strategies, financial support, and political will to bring these developments to the populations of endemic areas in equatorial Africa who are in primary need for intervention and for whom financial resources are scarce.

\section{Acknowledgments}

We thank many colleagues in the field for helpful discussions; and the Canadian Institutes of Health Research (CIHR), the intramural (Division of Intramural Research (DIR)), and extramural divisions of the National Institutes of Allergy and Infectious Diseases (NIAID), National Institutes of Health (NIH), and the Public Health Agency of Canada (PHAC), and the Defense Threat Reduction Agency for financial support of our work over the past decade. 


\section{References}

1. Sanchez, A.; Geisbert, TW.; Feldmann, H. Filoviridae: Marburg and Ebola viruses. In: Knipe, DM.; Howley, PM., editors. Fields virology. Philadelphia: Lippincott Williams \& Wilkins; 2006. p. 1409-1448.

2. Centers for Disease Control and Prevention. [accessed March 20, 2010] Bioterrorism agents/ diseases. http://www.bt.cdc.gov/agent/agentlist-category.asp\#a

3. Feldmann, H.; Geisbert, TW.; Jahrling, PB., et al. Filoviridae. In: Fauquet, C.; Mayo, MA.; Maniloff, J.; Desselberger, U.; Ball, LA., editors. Virus taxonomy: VIIIth report of the international committee on taxonomy of viruses. London: Elsevier/Academic Press; 2004. p. 645-653.

4. Kiley MP, Bowen ET, Eddy GA, et al. Filoviridae: a taxonomic home for Marburg and Ebola viruses? Intervirology. 1982; 18:24-32. [PubMed: 7118520]

5. Mühlberger E, Weik M, Volchkov VE, Klenk HD, Becker S. Comparison of the transcription and replication strategies of Marburg virus and Ebola virus by using artificial replication systems. J Virol. 1999; 73:2333-2342. [PubMed: 9971816]

6. Basler CF, Wang X, Mühlberger E, et al. The Ebola virus VP35 protein functions as a type I IFN antagonist. Proc Natl Acad Sci USA. 2000; 97:12289-12294. [PubMed: 11027311]

7. Noda T, Sagara H, Suzuki E, et al. Ebola virus VP40 drives the formation of virus-like filamentous particles along with GP. J Virol. 2002; 76:4855-4865. [PubMed: 11967302]

8. Reid SP, Leung LW, Hartman AL, et al. Ebola virus VP24 binds karyopherin alpha1 and blocks STAT1 nuclear accumulation. J Virol. 2006; 80:5156-5167. [PubMed: 16698996]

9. Sanchez A, Trappier SG, Mahy BW, Peters CJ, Nichol ST. The virion glycoproteins of Ebola viruses are encoded in two reading frames and are expressed through transcriptional editing. Proc Natl Acad Sci USA. 1996; 93:3602-3607. [PubMed: 8622982]

10. Volchkov VE, Becker S, Volchkova VA, et al. GP mRNA of Ebola virus is edited by the Ebola virus polymerase and by T7 and vaccinia virus polymerases. Virology. 1995; 214:421-430. [PubMed: 8553543]

11. Geisbert TW, Bausch DG, Feldmann H. Prospects of immunisation against Marburg and Ebola viruses. Rev Med Virol. 2010 published online July 23.

12. Siegert R, Shu HL, Slenczka W, Peters D, Muller G. On the etiology of an unknown human infection originating from monkeys. Dtsch Med Wochenschr. 1967; 92:2341-2343. (in German). [PubMed: 4294540]

13. WHO. Ebola haemorrhagic fever in Sudan, 1976. Bull World Health Organ. 1978; 56:247-270. [PubMed: 307455]

14. WHO. Ebola haemorrhagic fever in Zaire, 1976. Bull World Health Organ. 1978; 56:271-293. [PubMed: 307456]

15. Cox NJ, McCormick JB, Johnson KM, Kiley MP. Evidence for two subtypes of Ebola virus based on oligonucleotide mapping of RNA. J Infect Dis. 1983; 147:272-275. [PubMed: 6827144]

16. Le Guenno B, Formenty P, Wyers M, et al. Isolation and partial characterisation of a new strain of Ebola virus. Lancet. 1995; 345:1271-1274. [PubMed: 7746057]

17. Towner JS, Sealy TK, Khristova ML, et al. Newly discovered Ebola virus associated with hemorrhagic fever outbreak in Uganda. PLoS Pathog. 2008; 4 e1000212.

18. Jahrling PB, Geisbert TW, Johnson ED, Peters CJ, Dalgard DW, Hall WC. Preliminary report: isolation of Ebola virus from monkeys imported to USA. Lancet. 1990; 335:502-505. [PubMed: 1968529]

19. Dalgard DW, Hardy RJ, Pearson SL, et al. Combined simian haemorrhagic fever and Ebola virus infection in Cynomolgus monkeys. Lab Anim Sci. 1992; 42:152-157. [PubMed: 1318446]

20. Miranda ME, Ksiazek TG, Retuya TJ, et al. Epidemiology of Ebola (subtype Reston) virus in Philippines, 1996. J Infect Dis. 1999; 179(suppl 1):S115-S119. [PubMed: 9988174]

21. Barrette RW, Metwally SA, Rowland JM, et al. Discovery of swine as a host for the Reston ebolavirus. Science. 2009; 325:204-206. [PubMed: 19590002]

22. Groseth A, Feldmann H, Strong JE. The ecology of Ebola virus. Trends Microbiol. 2007; 15:408416. [PubMed: 17698361] 
23. Monath TP. Ecology of Marburg and Ebola viruses: speculations and directions for future research. J Infect Dis. 1999; 179(suppl 1):S127-S138. [PubMed: 9988176]

24. Breman JG, Johnson KM, van der Groen G, et al. A search for Ebola virus in animals in Democratic Republic of the Congo and Cameroon: ecologic, virologic and serologic surveys, 1979-1980. J Infect Dis. 1999; 179(suppl 1):S139-S147. [PubMed: 9988177]

25. Reiter P, Turell M, Coleman R, et al. Field investigations of an outbreak of Ebola haemorrhagic fever, Kikwit, Democratic Republic of the Congo, 1995: arthropod studies. J Infect Dis. 1999; 179(suppl 1):S148-S154. [PubMed: 9988178]

26. Leirs H, Mills JN, Krebs JW, et al. Search for the Ebola virus reservoir in Kikwit, Democratic Republic of the Congo: reflection on a vertebrate collection. J Infect Dis. 1999; 179(suppl 1):S155-S163. [PubMed: 9988179]

27. Morvan JM, Deubel V, Gounon P, et al. Identification of Ebola virus sequences present as RNA or DNA in organs of terrestrial small mammals of the Central African Republic. Microbes Infect. 1999; 1:1193-1201. [PubMed: 10580275]

28. Arata, AA.; Johnson, B. Approaches toward studies on potential reservoirs of viral haemorrhagic fever in southern Sudan (1977). In: Pattyn, SR., editor. Ebola virus haemorrhagic fever. Amsterdam: Elsevier, North-Holland; 1978. p. 191-200.

29. Swanepoel R, Leman PA, Burt FJ, et al. Experimental inoculation of plants and animals with Ebola virus. Emerg Infect Dis. 1996; 2:321-325. [PubMed: 8969248]

30. Leroy EM, Kumulungui B, Pourrut X, et al. Fruit bats as reservoirs of Ebola virus. Nature. 2005; 438:575-576. [PubMed: 16319873]

31. Pourrut X, Délicat A, Rollin PE, Ksiazek TG, Gonzalez JP, Leroy EM. Spatial and temporal patterns of Zaire ebolavirus antibody prevalence in the possible reservoir bat species. J Infect Dis. 2007; 196(suppl 2):S176-S183. [PubMed: 17940947]

32. Towner JS, Amman BR, Sealy TK, et al. Isolation of genetically diverse Marburg viruses from Egyptian fruit bats. PLoS Pathog. 2009; 5 e1000536.

33. Bausch DG, Nichol ST, Muyembe-Tamfum JJ, et al. Marburg haemorrhagic fever associated with multiple genetic lineages of virus. N Engl J Med. 2006; 355:909-919. [PubMed: 16943403]

34. Leroy EM, Epelboin A, Mondonge V, et al. Human Ebola outbreak resulting from direct exposure to fruit bats in Luebo, Democratic Republic of Congo, 2007. Vector Borne Zoonotic Dis. 2009; 9:723-728. [PubMed: 19323614]

35. Gupta M, Mahanty S, Greer P, et al. Persistent infection with Ebola virus under conditions of partial immunity. J Virol. 2004; 78:958-967. [PubMed: 14694127]

36. Strong JE, Wong G, Jones SE, et al. Stimulation of Ebola virus production from persistent infection through activation of the Ras/MAPK pathway. Proc Natl Acad Sci USA. 2008; 105:17982-17987. [PubMed: 18981410]

37. Pattyn, SR. Ebola virus haemorrhagic fever. Amsterdam: Elsevier, North-Holland; 1978.

38. Peters CJ, LeDuc LW. Ebola: the virus and the disease. J Infect Dis. 1999; 179(suppl 1):S1-S288. [PubMed: 9988155]

39. Feldmann H, Geisbert T, Kawaoka Y. Filoviruses: recent advances and future challenges. J Infect Dis. 2007; 196(suppl 2):S129-S443. [PubMed: 17940939]

40. Ksiazek TG, West CP, Rollin PE, et al. ELISA for the detection of antibodies to Ebola virus. J Infect Dis. 1999; 179(suppl 1):S192-S198. [PubMed: 9988184]

41. Rowe AK, Bertolli J, Khan AS, et al. Clinical, virologic, and immunologic follow-up of convalescent Ebola haemorrhagic fever patients and their household contacts, Kikwit, Democratic Republic of the Congo. J Infect Dis. 1999; 179(suppl 1):S28-S35. [PubMed: 9988162]

42. Ryabchikova E, Kolesnikova L, Smolina M, et al. Ebola virus infection in guinea pigs: presumable role of granulomatous inflammation in pathogenesis. Arch Virol. 1996; 141:909-921. [PubMed: 8678836]

43. Bray M, Davis K, Geisbert T, Schmaljohn C, Huggins J. A mouse model for evaluation of prophylaxis and therapy of Ebola haemorrhagic fever. J Infect Dis. 1998; 178:651-661. [PubMed: 9728532]

44. Connolly BM, Steele KE, Davis KJ, et al. Pathogenesis of experimental Ebola virus infection in guinea pigs. J Infect Dis. 1999; 179(suppl 1):S203-S217. [PubMed: 9988186] 
45. Bray M, Hatfill S, Hensley L, Huggins JW. Haematological, biochemical and coagulation changes in mice, guinea-pigs and monkeys infected with a mouse-adapted variant of Ebola Zaire virus. J Comp Pathol. 2001; 125:243-253. [PubMed: 11798241]

46. Geisbert TW, Pushko P, Anderson K, Smith J, Davis KJ, Jahrling PB. Evaluation in nonhuman primates of vaccines against Ebola virus. Emerg Infect Dis. 2002; 8:503-507. [PubMed: 11996686]

47. Dowell SF, Mukunu R, Ksiazek TG, Khan AS, Rollin PE, Peters CJ. Transmission of Ebola haemorrhagic fever: a study of risk factors in family members, Kikwit, Democratic Republic of the Congo, 1995. Commission de Lutte contre les Epidémies à Kikwit. J Infect Dis. 1999; 179(suppl 1):S87-S91. [PubMed: 9988169]

48. Khan AS, Tshioko FK, Heymann DL, et al. The reemergence of Ebola haemorrhagic fever, Democratic Republic of the Congo, 1995. Commission de Lutte contre les Epidémies à Kikwit. J Infect Dis. 1999; 179(suppl 1):S76-S86. [PubMed: 9988168]

49. Rodriguez LL, De Roo A, Guimard Y, et al. Persistence and genetic stability of Ebola virus during the outbreak in Kikwit, Democratic Republic of the Congo, 1995. J Infect Dis. 1999; 179(suppl 1):S170-S176. [PubMed: 9988181]

50. Zaki SR, Shieh WJ, Greer PW, et al. A novel immunohistochemical assay for the detection of Ebola virus in skin: implications for diagnosis, spread, and surveillance of Ebola haemorrhagic fever. Commission de Lutte contre les Epidémies à Kikwit. J Infect Dis. 1999; 179(suppl 1):S36S47. [PubMed: 9988163]

51. Geisbert TW, Hensley LE, Larsen T, et al. Pathogenesis of Ebola haemorrhagic fever in cynomolgus macaques: evidence that dendritic cells are early and sustained targets of infection. Am J Pathol. 2003; 163:2347-2370. [PubMed: 14633608]

52. Jahrling PB, Geisbert TW, Jaax NK, Hanes MA, Ksiazek TG, Peters CJ. Experimental infection of cynomolgus macaques with Ebola-Reston filoviruses from the 1989-1990 U.S. epizootic. Arch Virol. 1996; 11(suppl):115-134.

53. Emond RT, Evans B, Bowen ET, Lloyd G. A case of Ebola virus infection. BMJ. 1977; 2:541544. [PubMed: 890413]

54. International Society for Infectious Diseases. Ebola lab accident death—Russia (Siberia). 2004 May 22. Archive number 20040522.1377 http://www.promedmail.org.

55. International Society for Infectious Diseases. Ebola virus, needlestick injury - Germany: (Hamburg). 2009 Mar 17. Archive number 20090317.1084 http://www.promedmail.org.

56. Georges-Courbot MC, Sanchez A, Lu CY, et al. Isolation and phylogenetic characterization of Ebola viruses causing different outbreaks in Gabon. Emerg Infect Dis. 1997; 3:59-62. [PubMed: 9126445]

57. Jaax NK, Davis KJ, Geisbert TJ, et al. Lethal experimental infection of rhesus monkeys with Ebola-Zaire (Mayinga) virus by the oral and conjunctival route of exposure. Arch Pathol Lab Med. 1996; 120:140-155. [PubMed: 8712894]

58. Breman, JG.; Piot, P.; Johnson, KM., et al. The epidemiology of Ebola haemorrhagic fever in Zaire, 1976. In: Pattyn, S., editor. Ebola Virus Haemorrhagic Fever. Amsterdam: Elsevier/North Hollamnd; 1978. p. 103-124.

59. Geisbert TW, Daddario-Dicaprio KM, Geisbert JB, et al. Vesicular stomatitis virus-based vaccines protect nonhuman primates against aerosol challenge with Ebola and Marburg viruses. Vaccine. 2008; 26:6894-6900. [PubMed: 18930776]

60. Baskerville A, Fisher-Hoch SP, Neild GH, Dowsett AB. Ultrastructural pathology of experimental Ebola haemorrhagic fever virus infection. J Pathol. 1985; 147:199-209. [PubMed: 4067737]

61. Ryabchikova EI, Kolesnikova LV, Luchko SV. An analysis of features of pathogenesis in two animal models of Ebola virus infection. J Infect Dis. 1999; 179(suppl 1):S199-S202. [PubMed: 9988185]

62. Geisbert TW, Young HA, Jahrling PB, Davis KJ, Larsen T, Kagan E, Hensley LE. Pathogenesis of Ebola haemorrhagic fever in primate models: evidence that haemorrhage is not a direct effect of virus-induced cytolysis of endothelial cells. Am J Pathol. 2003; 163:2371-2382. [PubMed: 14633609] 
63. Zaki SR, Goldsmith CS. Pathologic features of filovirus infections in humans. Curr Top Microbiol Immunol. 1999; 235:97-116. [PubMed: 9893381]

64. Schnittler HJ, Feldmann H. Marburg and Ebola haemorrhagic fevers: does the primary course of infection depend on the accessibility of organ-specific macrophages? Clin Infect Dis. 1998; 27:404-406. [PubMed: 9709901]

65. Yang ZY, Duckers HJ, Sullivan NJ, Sanchez A, Nabel EG, Nabel GJ. Identification of the Ebola virus glycoprotein as the main viral determinant of vascular cell cytotoxicity and injury. Nat Med. 2000; 6:886-889. [PubMed: 10932225]

66. Murphy, FA. Pathogenesis of Ebola virus infection. In: Pattyn, SR., editor. Ebola Virus Haemorrhagic Fever. Amsterdam: Elsevier/North-Holland; 1978. p. 43-59.

67. Baize S, Leroy EM, Georges-Courbot MC, et al. Defective humoral responses and extensive intravascular apoptosis are associated with fatal outcome in Ebola virus-infected patients. Nat Med. 1999; 5:423-426. [PubMed: 10202932]

68. Baize S, Leroy EM, Mavoungou E, Fisher-Hoch SP. Apoptosis in fatal Ebola infection. Does the virus toll the bell for immune system? Apoptosis. 2000; 5:5-7. [PubMed: 11227491]

69. Geisbert TW, Hensley LE, Gibb TR, Steele KE, Jaax NK, Jahrling PB. Apoptosis induced in vitro and in vivo during infection by Ebola and Marburg viruses. Lab Invest. 2000; 80:171-186. [PubMed: 10701687]

70. Sanchez A, Lukwiya M, Bausch D, et al. Analysis of human peripheral blood samples from fatal and nonfatal cases of Ebola (Sudan) hemorrhagic fever: cellular responses, virus load, and nitric oxide levels. J Virol. 2004; 78:10370-10377. [PubMed: 15367603]

71. Hensley LE, Young HA, Jahrling PB, Geisbert TW. Proinflammatory response during Ebola virus infection of primate models: possible involvement of the tumor necrosis factor receptor superfamily. Immunol Lett. 2002; 80:169-179. [PubMed: 11803049]

72. Bosio CM, Aman MJ, Grogan C, et al. Ebola and Marburg viruses replicate in monocyte-derived dendritic cells without inducing the production of cytokines and full maturation. J Infect Dis. 2003; 188:1630-1638. [PubMed: 14639532]

73. Mahanty S, Hutchinson K, Agarwal S, McRae M, Rollin PE, Pulendran B. Cutting edge: impairment of dendritic cells and adaptive immunity by Ebola and Lassa viruses. J Immunol. 2003; 170:2797-2801. [PubMed: 12626527]

74. Baize S, Leroy EM, Georges AJ, et al. Inflammatory responses in Ebola virus-infected patients. Clin Exp Immunol. 2002; 128:163-168. [PubMed: 11982604]

75. Yaddanapudi K, Palacios G, Towner JS, et al. Implication of a retrovirus-like glycoprotein peptide in the immunopathogenesis of Ebola and Marburg viruses. FASEB J. 2006; 20:2519-2530. [PubMed: 17023517]

76. Volchkov VE, Blinov VM, Netesov SV. The envelope glycoprotein of Ebola virus contains an immunosuppressive-like domain similar to oncogenic retroviruses. FEBS Lett. 1992; 305:181184. [PubMed: 1299611]

77. Chepurnov AA, Tuzova MN, Ternovoy VA, Chernukhin IV. Suppressive effect of Ebola virus on $\mathrm{T}$ cell proliferation in vitro is provided by a $125-\mathrm{kDa}$ GP viral protein. Immunol Lett. 1999; 68:257-261. [PubMed: 10424429]

78. Villinger F, Rollin PE, Brar SS, et al. Markedly elevated levels of interferon (IFN)-gamma, IFNalpha, interleukin (IL)-2, IL-10, and tumor necrosis factor-alpha associated with fatal Ebola virus infection. J Infect Dis. 1999; 179(suppl 1):S188-S191. [PubMed: 9988183]

79. Ströher U, West E, Bugany H, Klenk HD, Schnittler HJ, Feldmann H. Infection and activation of monocytes by Marburg and Ebola viruses. J Virol. 2001; 75:11025-11033. [PubMed: 11602743]

80. Baize S, Leroy EM, Georges AJ, et al. Inflammatory responses in Ebola virus-infected patients. Clin Exp Immunol. 2002; 128:163-168. [PubMed: 11982604]

81. Harcourt BH, Sanchez A, Offermann MK. Ebola virus inhibits induction of genes by doublestranded RNA in endothelial cells. Virology. 1998; 252:179-188. [PubMed: 9875327]

82. Harcourt BH, Sanchez A, Offermann MK. Ebola virus selectively inhibits responses to interferons, but not to interleukin-1beta, in endothelial cells. J Virol. 1999; 73:3491-3496. [PubMed: 10074208] 
83. Basler CF, Mikulasova A, Martinez-Sobrido L, et al. The Ebola virus VP35 protein inhibits activation of interferon regulatory factor 3. J Virol. 2003; 77:7945-7956. [PubMed: 12829834]

84. Balser, CF.; Palese, P. Modulation of innate immunity by filoviruses. In: Klenk, HD.; Feldmann, H., editors. Ebola and Marburg Viruses-Molecular and Cellular Biology. Norfolk, VA: Horizon Bioscience; 2004. p. 305-349.

85. Ebihara H, Takada A, Kobasa D, et al. Molecular determinants of Ebola virus virulence in mice. PLoS Pathog. 2006; 2:e73. [PubMed: 16848640]

86. Volchkov VE, Chepurnov AA, Volchkova VA, Ternovoj VA, Klenk HD. Molecular characterization of guinea pig-adapted variants of Ebola virus. Virology. 2000; 277:147-155. [PubMed: 11062045]

87. Isaacson, M.; Sureau, P.; Courteille, G.; Pattyn, SR. Evola Virus Haemorrhagic Fever. Amsterdam: Elsevier/North-Holland; 1978. Clinical aspects of Ebola virus disease at the Ngaliema hospital, Kinshasa, Zaire, 1976; p. 15-20.

88. Levi M. Disseminated intravascular coagulation. Crit Care Med. 2007; 35:2191-2195. [PubMed: 17855836]

89. Fisher-Hoch SP, Platt GS, Neild GH, et al. Pathophysiology of shock and haemorrhage in a fulminating viral infection (Ebola). J Infect Dis. 1985; 152:887-894. [PubMed: 4045253]

90. Fisher-Hoch SP, Brammer TL, Trappier SG, et al. Pathogenic potential of filoviruses: role of geographic origin of primate host and virus strain. J Infect Dis. 1992; 166:753-763. [PubMed: 1527410]

91. Geisbert TW, Young HA, Jahrling PB, Davis KJ, Kagan E, Hensley LE. Mechanisms underlying coagulation abnormalities in ebola haemorrhagic fever: overexpression of tissue factor in primate monocytes/macrophages is a key event. J Infect Dis. 2003; 188:1618-1629. [PubMed: 14639531]

92. International Society for Infectious Diseases. [accessed March 28, 2010] Marburg Hemorrhagic Fever-United States of America—Ex Uganda. 2008. Archive number 20080710.2107 http://www.promedmail.org

93. International Society for Infectious Diseases. [accessed March 28, 2010] Marburg Hemorrhagic Fever-The Netherlands-Ex Uganda. 2009. Archive number 20090131.0423 http://www.promedmail.org

94. Strong, JE.; Grolla, A.; Jahrling, PB.; Feldmann, H. Filoviruses and arenaviruses. In: Detrick, B.; Hamilton, RG.; Folds, JD., editors. Manual of Molecular and Clinical Laboratory Immunology. 7th edn.. Herndon, Virginia: ASM Press; 2006. p. 774-790.

95. Elliott LH, McCormick JB, Johnson KM. Inactivation of Lassa, Marburg, and Ebola viruses by gamma irradiation. J Clin Microbiol. 1982; 16:704-708. [PubMed: 7153317]

96. Towner JS, Sealy TK, Ksiazek TG, Nichol ST. High-throughput molecular detection of haemorrhagic fever virus threats with applications for outbreak settings. J Infect Dis. 2007; 196(suppl 2):S205-S212. [PubMed: 17940951]

97. Feldmann H, Jones S, Klenk HD, Schnittler HJ. Ebola virus: from discovery to vaccine. Nat Rev Immunol. 2003; 3:677-685. [PubMed: 12974482]

98. Grolla A, Lucht A, Dick D, Strong J, Feldmann H. Laboratory diagnosis of Ebola and Marburg haemorrhagic fever. Bull Soc Pathol Exot. 2005; 98:205-209. [PubMed: 16267962]

99. Towner JS, Rollin PE, Bausch DG, et al. Rapid diagnosis of Ebola haemorrhagic fever by reverse transcription-PCR in an outbreak setting and assessment of patient viral load as a predictor of outcome. J Virol. 2004; 78:4330-4341. [PubMed: 15047846]

100. Lloyd ES, Zaki SR, Rollin PE, et al. Long-term disease surveillance in Bandundu region, Democratic Republic of the Congo: a model for early detection and prevention of Ebola haemorrhagic fever. J Infect Dis. 1999; 179(suppl 1):S274-S280. [PubMed: 9988195]

101. [accessed April 4, 2010] Infection control for viral haemorrhagic fevers in the African health care setting. http://www.who.int/csr/resources/publications/ebola/WHO_EMC_ESR_98_2_EN/en/print.html

102. Smith PW, Anderson AO, Christopher GW, et al. Designing a biocontainment unit to care for patients with serious communicable diseases: a consensus statement. Biosecur Bioterror. 2006; 4:351-365. [PubMed: 17238819] 
103. Risi GF, Bloom M, Hoe N, et al. Preparing a community to care for work-related exposures to biosafety level 3 and 4 agents. Emerg Infect Dis. 2010; 16:373-378. [PubMed: 20202409]

104. Huggins JW. Prospects for treatment of viral haemorrhagic fevers with ribavirin, a broadspectrum antiviral drug. Rev Infect Dis. 1989; 11(suppl 4):S750-S761. [PubMed: 2546248]

105. Ignatyev G, Steinkasserer A, Streltsova M, Atrasheuskaya A, Agafonov A, Lubitz W. Experimental study on the possibility of treatment of some haemorrhagic fevers. J Biotechnol. 2000; 83:67-76. [PubMed: 11000462]

106. Geisbert TW, Hensley LE, Kagan E, et al. Postexposure protection of guinea pigs against a lethal ebola virus challenge is conferred by RNA interference. J Infect Dis. 2006; 193:1650-1657. [PubMed: 16703508]

107. Warfield KL, Swenson DL, Olinger GG, et al. Gene-specific countermeasures against Ebola virus based on antisense phosphorodiamidate morpholino oligomers. PLoS Pathog. 2006; 2:e1. [PubMed: 16415982]

108. Geisbert TW, Lee ACH, Robbins M, et al. Postexposure protection of non-human primates against a lethal Ebola virus challenge with RNA interference: a proof-of-concept study. Lancet. 2010; 375:1896-1905. [PubMed: 20511019]

109. Geisbert TW, Hensley LE, Jahrling PB, et al. Treatment of Ebola virus infection with a recombinant inhibitor of factor VIIa/tissue factor: a study in rhesus monkeys. Lancet. 2003; 362:1953-1958. [PubMed: 14683653]

110. Hensley LE, Stevens EL, Yan SB, et al. Recombinant human activated protein C for the postexposure treatment of Ebola haemorrhagic fever. J Infect Dis. 2007; 196(suppl 2):S390S399. [PubMed: 17940975]

111. Garbutt M, Liebscher R, Wahl-Jensen V, et al. Properties of replication-competent vesicular stomatitis virus vectors expressing glycoproteins of filoviruses and arenaviruses. J Virol. 2004; 78:5458-5465. [PubMed: 15113924]

112. Feldmann H, Jones SM, Daddario-DiCaprio KM, et al. Effective post-exposure treatment of Ebola infection. PLoS Pathog. 2007; 3:e2. [PubMed: 17238284]

113. Geisbert TW, Daddario-DiCaprio KM, Williams KJ, et al. Recombinant vesicular stomatitis virus vector mediates postexposure protection against Sudan Ebola haemorrhagic fever in nonhuman primates. J Virol. 2008; 82:5664-5668. [PubMed: 18385248]

114. Tuffs A. Experimental vaccine may have saved Hamburg scientist from Ebola fever. BMJ. 2009; 338:b1223. [PubMed: 19307268]

115. Bray M, Paragas J. Experimental therapy of filovirus infections. Antiviral Res. 2002; 54:1-17. [PubMed: 11888653]

116. Mupapa K, Massamba M, Kibadi K, et al. Treatment of Ebola haemorrhagic fever with blood transfusions from convalescent patients. International Scientific and Technical Committee. J Infect Dis. 1999; 179(suppl 1):S18-S23. [PubMed: 9988160]

117. Maruyama T, Rodriguez LL, Jahrling PB, et al. Ebola virus can be effectively neutralized by antibody produced in natural human infection. J Virol. 1999; 73:6024-6030. [PubMed: 10364354]

118. Wilson JA, Hevey M, Bakken R, et al. Epitopes involved in antibody-mediated protection from Ebola virus. Science. 2000; 287:1664-1666. [PubMed: 10698744]

119. Parren PW, Geisbert TW, Maruyama T, Jahrling PB, Burton DR. Pre- and postexposure prophylaxis of Ebola virus infection in an animal model by passive transfer of a neutralizing human antibody. J Virol. 2002; 76:6408-6412. [PubMed: 12021376]

120. Mikhailov VV, Borisevich IV, Chernikova NK, Potryvaeva NV, Krasnianskii VP. The evaluation in hamadryas baboons of the possibility for the specific prevention of Ebola fever. Vopr Virusol. 1994; 39:82-84. [in Russian]. [PubMed: 8017061]

121. Jahrling PB, Geisbert J, Swearengen JR, et al. Passive immunization of Ebola virus-infected cynomolgus monkeys with immunoglobulin from hyperimmune horses. Arch Virol. 1996; 11(suppl 1):135-140.

122. Jahrling PB, Geisbert JB, Swearengen JR, Larsen T, Geisbert TW. Ebola haemorrhagic fever: evaluation of passive immunotherapy in nonhuman primates. J Infect Dis. 2007; 196(suppl 2):S400-S403. [PubMed: 17940976] 
123. Oswald WB, Geisbert TW, Davis KJ, et al. Neutralizing antibody fails to impact the course of Ebola virus infection in monkeys. PLoS Pathog. 2007; 3:e9. [PubMed: 17238286]

124. Feldmann H, Jones SM, Schnittler HJ, Geisbert T. Therapy and prophylaxis of Ebola virus infections. Curr Opin Investig Drugs. 2005; 6:823-830.

125. Sullivan NJ, Sanchez A, Rollin PE, Yang ZY, Nabel GJ. Development of a preventive vaccine for Ebola virus infection in primates. Nature. 2000; 408:605-609. [PubMed: 11117750]

126. Sullivan NJ, Geisbert TW, Geisbert JB, et al. Accelerated vaccination for Ebola virus haemorrhagic fever in non-human primates. Nature. 2003; 424:681-684. [PubMed: 12904795]

127. Swenson DL, Wang D, Luo M, et al. Vaccine to confer to nonhuman primates complete protection against multistrain Ebola and Marburg virus infections. Clin Vaccine Immunol. 2008; 15:460-467. [PubMed: 18216185]

128. Brandt CD, Kim HW, Vargosko AJ, et al. Infections in 18000 infants and children in a controlled study of respiratory tract disease. I. Adenovirus pathogenicity in relation to serologic type and illness syndrome. Am J Epidemiol. 1969; 90:484-500. [PubMed: 4312064]

129. Cohen J. AIDS research. Did Merck's failed HIV vaccine cause harm? Science. 2007; 318:10481049. [PubMed: 18006711]

130. Warfield KL, Swenson DL, Olinger GG, Kalina WV, Aman MJ, Bavari S. Ebola virus-like particle-based vaccine protects nonhuman primates against lethal Ebola virus challenge. J Infect Dis. 2007; 196:S430-S437. [PubMed: 17940980]

131. Halfmann P, Kim JH, Ebihara H, et al. Generation of biologically contained Ebola viruses. Proc Natl Acad Sci USA. 2008; 105:1129-1133. [PubMed: 18212124]

132. Halfmann P, Ebihara H, Marzi A, et al. Replication-deficient ebolavirus as a vaccine candidate. J Virol. 2009; 83:3810-3815. [PubMed: 19211761]

133. Bukreyev A, Yang L, Zaki SR, et al. A single intranasal inoculation with a paramyxovirusvectored vaccine protects guinea pigs against a lethal-dose Ebola virus challenge. J Virol. 2006; 80:2267-2279. [PubMed: 16474134]

134. Bukreyev A, Rollin PE, Tate MK, et al. Successful topical respiratory tract immunization of primates against Ebola virus. J Virol. 2007; 81:6379-6388. [PubMed: 17428868]

135. Jones SM, Feldmann H, Ströher U, et al. Live attenuated recombinant vaccine protects nonhuman primates against Ebola and Marburg viruses. Nat Med. 2005; 11:786-790. [PubMed: 15937495]

136. Geisbert TW, Daddario-Dicaprio KM, Lewis MG, et al. Vesicular stomatitis virus-based ebola vaccine is well-tolerated and protects immunocompromised nonhuman primates. PLoS Pathog. 2008; 4 e1000225.

137. Yang L, Sanchez A, Ward JM, Murphy BR, Collins PL, Bukreyev A. A paramyxovirus-vectored intranasal vaccine against Ebola virus is immunogenic in vector-immune animals. Virology. 2008; 377:255-264. [PubMed: 18570964]

138. Qiu X, Fernando L, Alimonti JB, et al. Mucosal immunization of cynomolgus macaques with the VSVDeltaG/ZEBOV GP vaccine stimulates strong Ebola GP-specific immune responses. PLoS One. 2009; 4:e5447. [PubMed: 19421329]

139. Sullivan NJ, Martin JE, Graham BS, Nabel GJ. Correlates of protective immunity for Ebola vaccines: implications for regulatory approval by the animal rule. Nat Rev Microbiol. 2009; 7:393-400. [PubMed: 19369954]

140. Geisbert TW, Geisbert JB, Leung A, et al. Single injection vaccine protects nonhuman primates against Marburg virus and three species of Ebola virus. J Virol. 2009; 83:7296-7304. [PubMed: 19386702] 


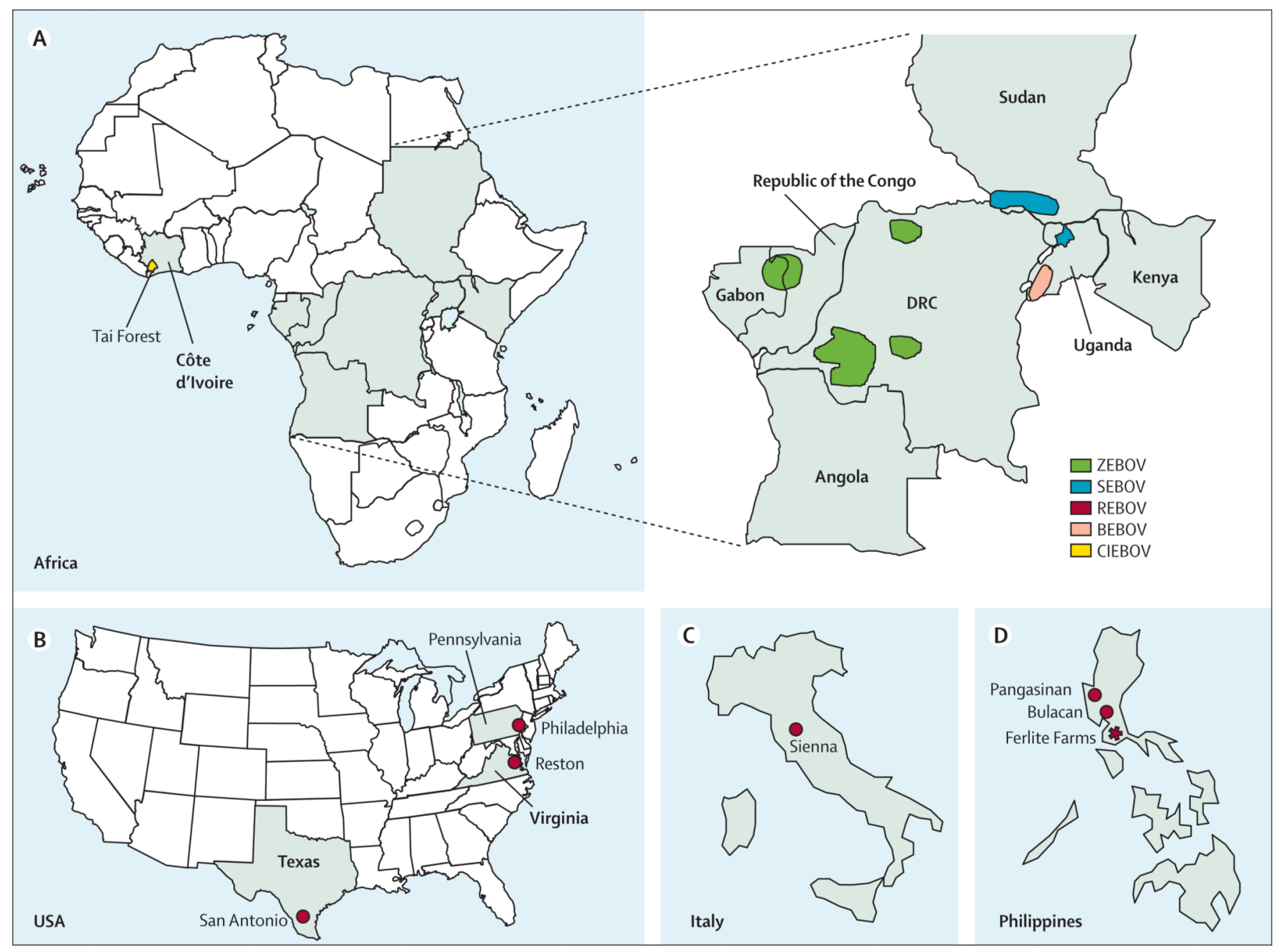

Figure 1. Locations of Ebolavirus infections and outbreaks

(A) Regions in Africa (approximate distribution $10^{\circ}$ north and south of the equator) with reported outbreaks of Ebola haemorrhagic fever caused by the three central African species of Ebola virus, Zaire Ebola virus (ZEBOV), Sudan Ebola virus (SEBOV), and Bundibugyo Ebola virus (BEBOV). The Tai Forest region in Côte d'Ivoire reported the only case so far of Ebola virus in western Africa caused by the species Côte d'Ivoire Ebola virus (CIEBOV). (B) Reston ebolavirus REBOV has been introduced several times through imported macaques into USA from 1989 to 1996 (Philadelphia, PA; Reston, VA; San Antonio, TX) and into Italy (Siena) in 1992 (C). The source of the introduction in all cases of REBOV has been a primate export facility in the Philippines (Ferlite farm) (D). Animals of this farm have been diagnosed with REBOV infection several times in the 1990s. REBOV has been detected in pigs on two farms in the Philippines (Pangasinan, Bulacan). DRC=Democratic Republic of the Congo. 


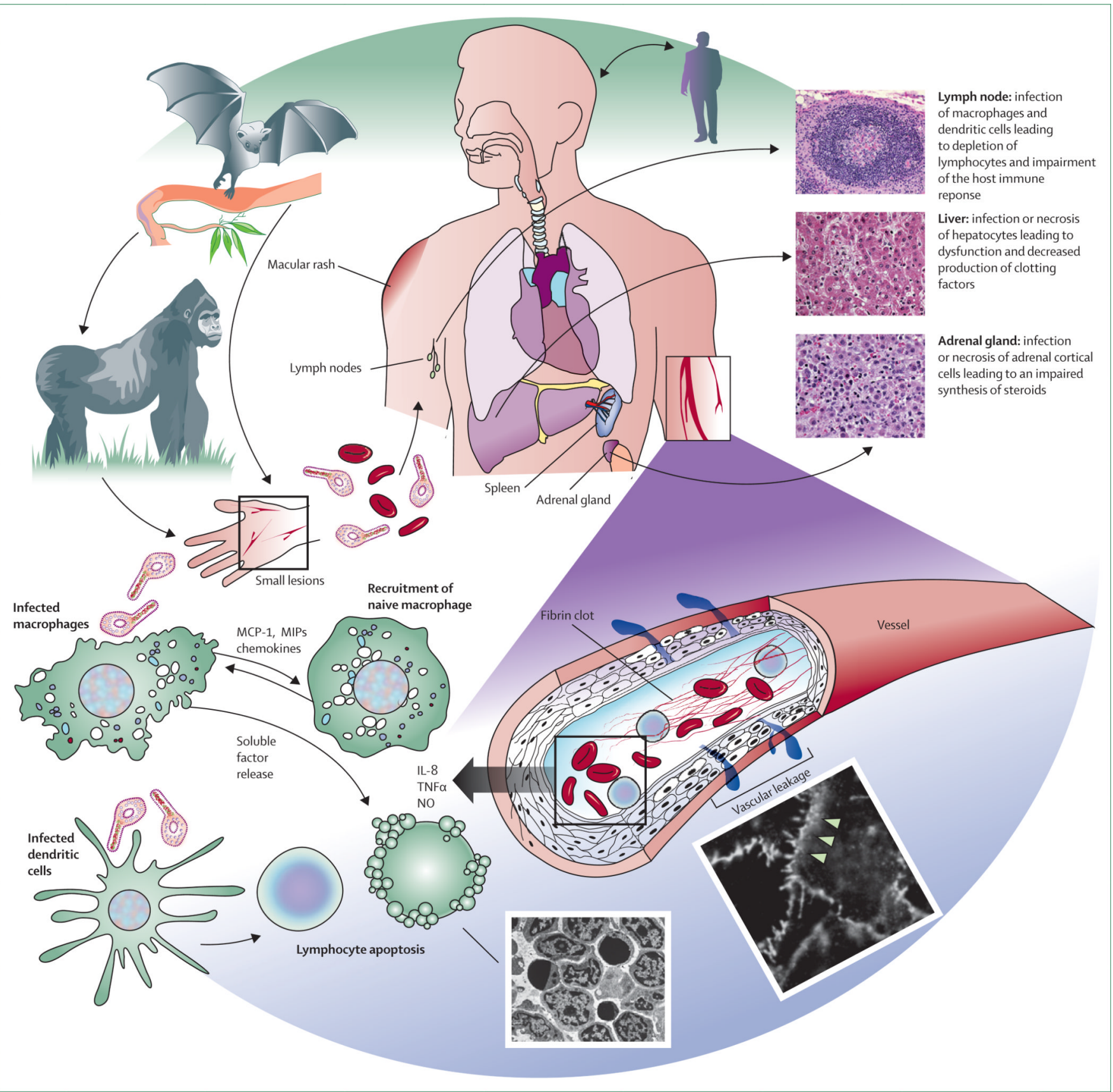

Figure 2. Model of Ebola virus pathogenesis

Virus spreads from the initial infection site (small lesions) to regional lymph nodes, liver, and spleen. Although Ebola virus does not infect lymphocytes, their rapid loss by apoptosis is a prominent feature of disease. The direct interaction of lymphocytes with viral proteins cannot be discounted as having a role in their destruction, but the substantial loss of lymphocytes probably results from a combination of factors including infection-mediated impairment of dendritic cells and release of soluble factors from monocytes and macrophages. Soluble factors released from target cells also contribute to the impairment of the vascular system leading to vascular leakage as demonstrated here in cultures of endothelial cells (white arrowheads). The systemic virus spread and replication, the general dysregulation of the host immune response, the coagulation abnormalities, the impairment of 
the vascular system, and hypotension all together finally result in shock and multiorgan failure. $\mathrm{IL}=$ interleukin. $\mathrm{MCP}-1=$ monocyte chemoattractant protein-1. MIPs=macrophage inflammatory proteins. $\mathrm{NO}=$ nitric oxide. $\mathrm{TNFa}=$ tumour necrosis factor $\mathrm{a}$. 

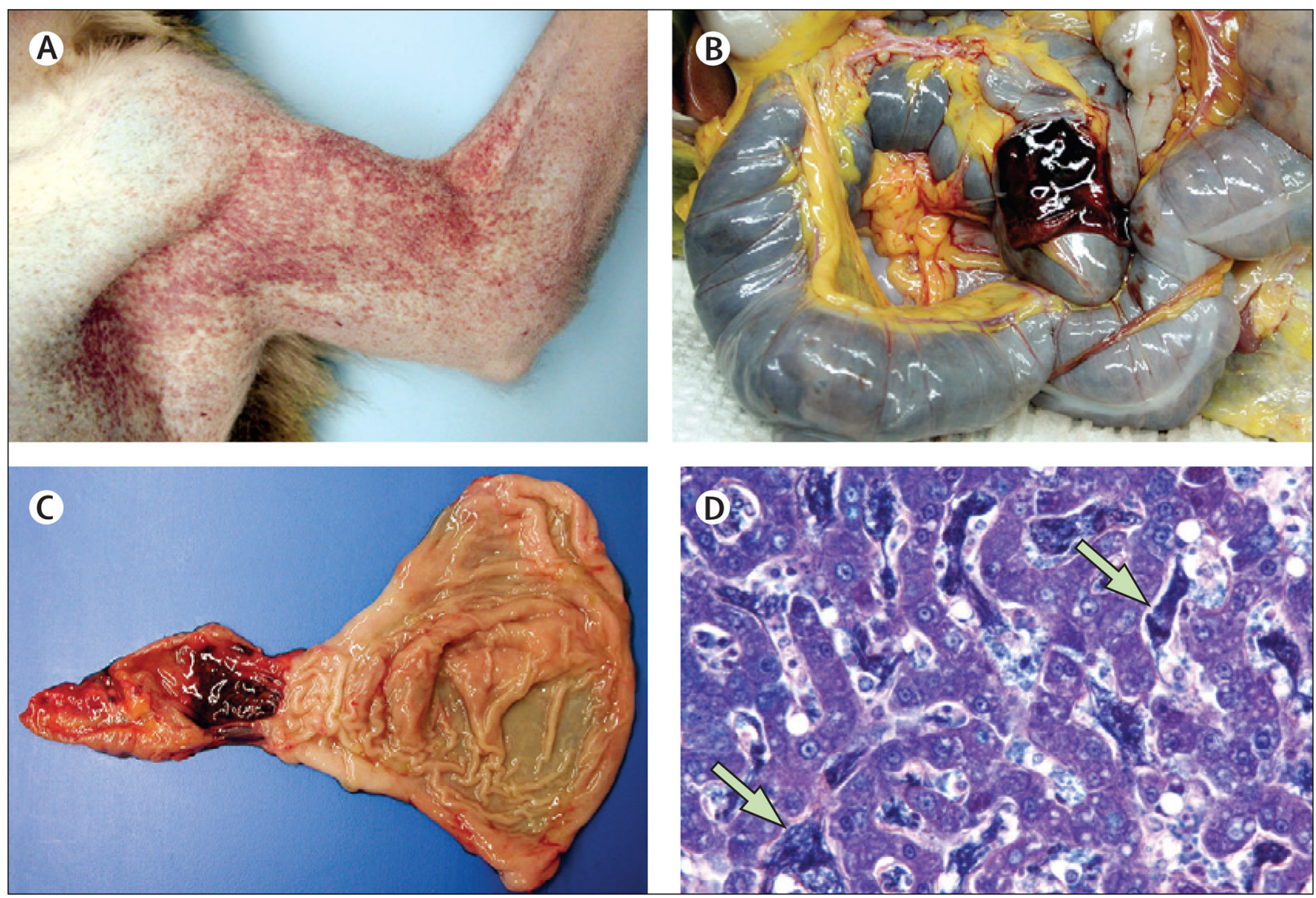

Figure 3. Haemorrhagic manisfestations noted in non-human primates infected with Ebola virus Petechiae on the arm and axillary region of a Cynomolgus monkey infected with Sudan Ebola virus (A). Also shown are haemorrhages in the ileum (B) and a gastroduodenal lesion (C) from a Cynomolgus monkey infected with Sudan Ebola virus and fibrin thrombi (arrows) in sinusoids of a rhesus monkey infected with Zaire Ebola virus (D). 
Table

Treatment and prophylaxis of Ebola haemorrhagic fever

\begin{tabular}{|c|c|c|}
\hline & Success in animals & Issues and concerns \\
\hline \multicolumn{3}{|l|}{ Treatment approach } \\
\hline Antibody therapy & $\begin{array}{l}\text { Efficacy in rodents but not in non-human } \\
\text { primates }\end{array}$ & $\begin{array}{l}\text { Escape mutants; genetic variability; } \\
\text { antibody-dependent enhancement of } \\
\text { infection }\end{array}$ \\
\hline \multicolumn{3}{|l|}{ Antisense oligonucleotides } \\
\hline Phosphorodiamidate morpholino oligonucleotides & $\begin{array}{l}\text { Efficacy in rodents and non-human primates } \\
\text { (latter prophylactic only) }\end{array}$ & Genetic variation; delivery \\
\hline Small interfering RNAs & Efficacy in rodents and non-human primates & Genetic variation; delivery \\
\hline \multicolumn{3}{|l|}{ Inflammatory modulators } \\
\hline Type I interferons & $\begin{array}{l}\text { Efficacy in rodents but not in non-human } \\
\text { primates }\end{array}$ & Manipulation of immune system \\
\hline S-adenosylhomocysteine hydrolase inhibitors & $\begin{array}{l}\text { Efficacy in rodents but not in non-human } \\
\text { primates }\end{array}$ & Manipulation of immune system \\
\hline \multicolumn{3}{|l|}{ Coagulation modulators } \\
\hline Heparin sulfate & $\begin{array}{l}\text { Efficacy in humans questionable; not tested } \\
\text { in animals }\end{array}$ & Manipulation of coagulation \\
\hline Tissue factor pathway inhibitors & $\begin{array}{l}\text { Not tested in rodents; partial protection in } \\
\text { non-human primates }\end{array}$ & Manipulation of coagulation \\
\hline Activated protein $\mathrm{C}$ & $\begin{array}{l}\text { Not tested in rodents; partial protection in } \\
\text { non-human primates }\end{array}$ & Manipulation of coagulation \\
\hline \multicolumn{3}{|l|}{ Vaccination approach } \\
\hline \multicolumn{3}{|l|}{ Postexposure vaccination } \\
\hline Vesicular stomatitis virus & Efficacy in rodents and non-human primates & $\begin{array}{l}\text { Efficacy dependent on filovirus species } \\
\text { and time of treatment start }\end{array}$ \\
\hline \multicolumn{3}{|l|}{ Pre-exposure vaccination } \\
\hline Adenovirus type 5 & $\begin{array}{l}\text { Efficacy in rodents and non-human } \\
\text { primates; one dose; clinical trials }\end{array}$ & Pre-existing immunity; high dose \\
\hline Human parainfluenza virus type 3 & $\begin{array}{l}\text { Efficacy in rodents and non-human } \\
\text { primates; two doses needed for non-human } \\
\text { primates }\end{array}$ & $\begin{array}{l}\text { Pre-existing immunity; safety } \\
\text { (replication-competent) }\end{array}$ \\
\hline Vesicular stomatitis virus & $\begin{array}{l}\text { Efficacy in rodents and non-human } \\
\text { primates; one dose }\end{array}$ & Safety (replication-competent) \\
\hline Virus-like particles & $\begin{array}{l}\text { Efficacy in rodents and non-human } \\
\text { primates; three doses needed for non-human } \\
\text { primates }\end{array}$ & Boost immunisation needed; production \\
\hline Recombinant Ebola virus without VP35 & Efficacy in rodents & Safety \\
\hline
\end{tabular}

Only approaches that have shown in-vivo efficacy have been listed. 